$551.513: 551.515: 551.582: 551.585$

\title{
Four Stages of the Rainy Season in Early Summer over East Asia (Part I)
}

\author{
By Masatoshi M. Yoshino \\ Faculty of Science, Tokyo Kyoiku University, Tokyo \\ (Manuscript received 25 June 1965)
}

\begin{abstract}
The rainy season in early summer over East Asia was divided into four stages by considering the positions of frontal zones at sea level and the features of westerly zonal winds at the $500-\mathrm{mb}$ level detected on the isopleth charts along $120^{\circ} \mathrm{E}$ and $140^{\circ} \mathrm{E}$. The chronicle of Stages I-IV for each ten days in May, June and July, 1950-1963, was first given. Secondly, the macro-scale situations of each Stage, such as the patterns of 500-mb contours over the northern hemisphere, the patterns of zonal winds at $500-\mathrm{mb}$ level over East Asia, the vertical profiles of zonal winds along $140^{\circ} \mathrm{E}$ and the positions of frontal zones at $850-\mathrm{mb}$ level, were described by compiling the states for respective Stages. According to these maps and profiles, it can be found that the situations in Stage I were a winter type, those from Stage II showed a type of summer character and a true summer type appeared in Stage IV. Finally, the results of present division were compared with the others' to deal with the regional and time differences in the beginning and the end of the rainy season in connection with Stages I-IV.
\end{abstract}

\section{Introduction}

The rainy season in early summer, called Mai-yü in China and Bai-u in Japan, is one of the outstanding conditions of climate in East Asia. It has long been called attention in meteorology and climatology in Japan, China and other countries, but few have been done in those studies from a consistent viewpoint over the whole region of East Asia. Even though the rainy season in China appears nearly at the same time as that in Japan and their characteristics resemble between them, they have some what different structures both meteorologically and climatologically if we see them in detail. This was shown in the preceding study by the present writer, by analysing the distribution of the extreme value and the local difference of secular change of precipitation, the positions of frontal zones and westerly jet streams over East Asia (Yoshino, 1963).

In this paper, Part I, it is intended to make clear the stage division of the rainy season in every year over East Asia and to describe the synoptic patterns of the northern hemisphere, the state of zonal winds at $500-\mathrm{mb}$ level over Asia, the structures not only of the troposphere but of the stratosphere, and the frontal zones at the $850-\mathrm{mb}$ level in each Stage. Finally, Stages presented are compared with the beginning or last dates of the rainy seasons in Japan and in China determined by the other researchers and the relationships between them are dealt with. The rainfall distributions in the season in Japan and her surrounding regions were presented in the last paper (Yoshino, 1964), but those in the whole region of East Asia are given in detail in the Part II, which will be published as the next paper.

\section{The previous studies}

The shifting of the rainy season from south to north, as a sequent of advance of the summer monsoon over China, was first studied by $\mathrm{Tu}$ and Hwang $(1944,1945)$, by presenting the shifting of isochrones of the mean wet-bulb potential temperatures of $20^{\circ} \mathrm{C}$ and $24^{\circ} \mathrm{C}$. The period of Bai-u season has been studied by Takahashi and others from early days and there is a detailed decription on it over Japan (Takahashi, 1955).

The weather cycle in the period of Bai-u, 
in other words, stagelike process of Bai-u, was analysed in connection with the singularity deduced from 34-year mean value for every day (Oosawa, 1951). On the other hand, Murakami has clarified the last stage of Bai$\mathrm{u}$ season in Japan in relation to the positional change of jet streams over East Asia (Murakami, 1951).

Since then, there have been published many papers which would contribute to the stage division of the rainy season. They are grouped roughly into five according to phenomena analysed: (1) mean zonal winds at the 500-mb level or so (Matsumoto et al., 1954; Suda and Asakura, 1955; Murakami, 1955, Dao and Chen, 1957 ; Dao, 1958 ; Staff Members Acad. Sinica, 1957), (2) synoptic or aerological conditions (Liu and Wu, 1956 ; Tang, 1957), (3) flow patterns in relation to fronts or convergence zones (Thompson, 1951; Ramage, 1951, 1952 ; Flohn, 1950, 1957), (4) water vapour transport (Flohn and Oeckel, 1956; Murakami, 1959), and (5) division of the rainy season in Japan, China or India (Takahashi, 1965 ; Zou et al., 1964 ; Ramanathan, 1960) and East Asia (Kao and Shih, 1962 ; Yoshino, 1963, 1964).

Summarizing the results of these studies, one may come to the following conclusions: (1) The simplest is of course to determine the beginning and last date of the rainy season, although it can be made from various standpoints. (2) There are, however, divisions of two stages, such as the stages of pre-rainy season and of main rainy season.
(3) It can also be noticed that there exists an apparent situation of late Bai-u season or post-Mai-yü period. (4) The occurrences of aerological and synoptic conditions over East Asia, which control the rainy season in China or Japan in every year, were reasonably earlier than the beginning date determined for Japan or for the Yangtze River region, China.

\section{Four stages of the rainy season}

\section{i) Criteria of the division}

Based on the conclusion derived from the previous studies mentioned above and on the results of my earlier work (Yoshino, 1963), the rainy season was divided into four stages. Each stage was determined both by the positions of frontal zones at sea level and by special features of axis of westerly wind maximum detected on the isopleth charts. The former was made possible referring to the atlases of frontal zones for each ten days of May, June and July, 1950-1963 (Data 1, 2), which give the distribution of the occurrence frequency of fronts summed up in each $2^{\circ} \times$ $2^{\circ}$ square of the officially published weather maps (Data 3). The latter was done using the isopleth charts of zonal component of geostrophic wind velocity at the $500-\mathrm{mb}$ level for 5-day mean value along $120^{\circ} \mathrm{E}$ and also $140^{\circ} \mathrm{E}$. The stages were determined for every ten days.

Characteristics of the four stages are as follows (Fig. 1 gives an example for determining stages in 1953):

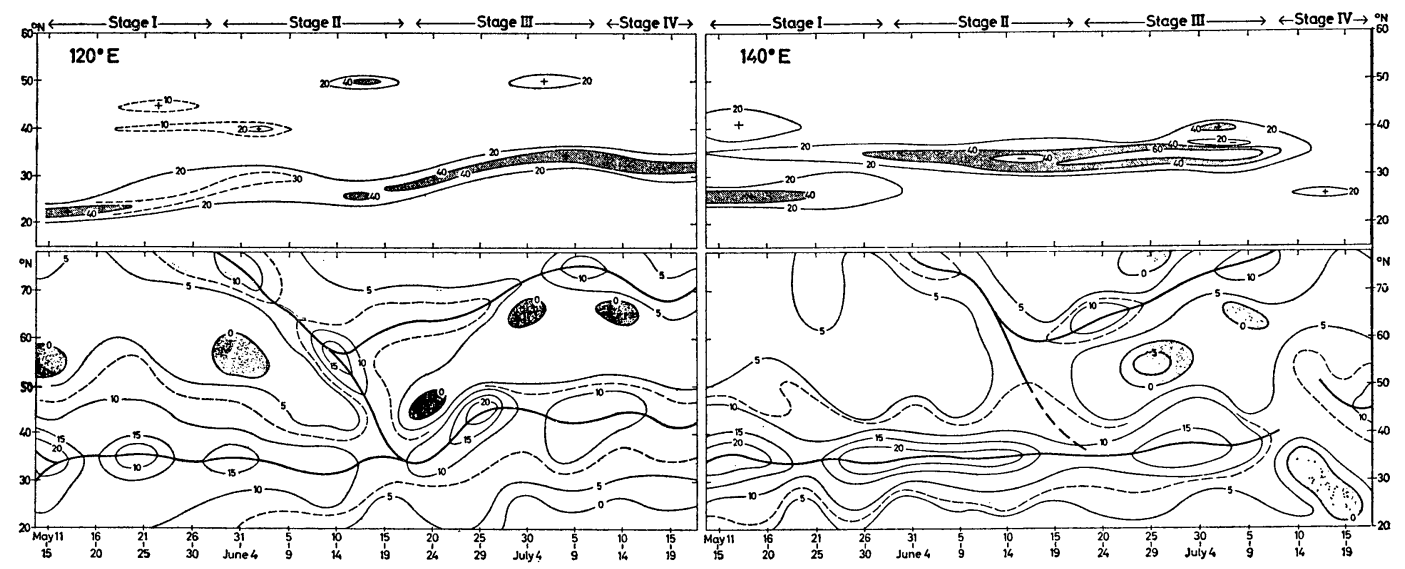

Fig. 1. An example for determining Stages I-IV in 1953. Lower part; isopleth of the geostrophic wind velocity $(\mathrm{m} / \mathrm{s})$ at the $500-\mathrm{mb}$ level. Westerly: positive. Upper part; isopleth of the occurrence frequency $(\%)$ of fronts at sea level. Left: along $120^{\circ} \mathrm{E}$. Right: along $140^{\circ} \mathrm{E}$. 
Stage I-An apparent frontal zone, though its west-east length is not longer than several hundreds kilometers, appears in southern China (Stage $I_{a}$ ) or along the Pacific coast of Japan (Stage $I_{b}$ ). The axis of subtropical westerly wind maximum runs about along $35^{\circ} \mathrm{N}$ and from this axis to the north there appears a gentle, uniform decrease of westerly wind velocity. "Forerunner of Bai-u" (Bai-u no hashiri) called in Japan corresponds to Stage $\mathrm{I}_{\mathrm{b}}$.

Stage II-The frontal zone begins to develop from central China to the Pacific coast of Japan. This Stage can be more easily defined by the conditions of the axis of westerly wind maximum: This is the time when the polar axis, coming down from high latitudes, joins to another axis, subtropical one along $35^{\circ} \mathrm{N}$. In this Stage the rainy season begins from the Yangtze River region to the southwestern part of Japan.*

Stage III-The marked frontal zone develops from central China to Japan. This frontal zone is a quite striking one, not only in its occurrence frequency $(40-70 \%)$, but also in its extending distance $(4,000-5,000$ $\mathrm{km})$. The axis of westerly wind maximum runs along $35^{\circ} \mathrm{N}$ and the easterly region appears around $45-55^{\circ} \mathrm{N}$, as a result of an intense meandering of westerly. North of this region, about $60^{\circ} \mathrm{N}$ or further north, there exists another weak westerly wind maximum, polar one. This Stage is a climax of the rainy season over East Asia.

Stage IV-The frontal zone at the sea level sometimes remains in China, but is obscure and shifted to north over East Asia as a whole. The axis of westerly wind maximum along $35^{\circ} \mathrm{N}$ retreats to $45^{\circ} \mathrm{N}$ or further at 500 $\mathrm{mb}$ level and another one is placed about $80^{\circ} \mathrm{N}$ or disappears. As far as the zonal wind pattern at the $500-\mathrm{mb}$ level is concerned, the rainy season is over by this Stage. Japan sometimes suffers, however, from grave disasters caused by local, heavy rainfall in this Stage.

\section{ii) Results of division for 1950-1963}

Applying the division critera described

* In some years, there appears a short pause of the rainy weather (Bai-u no nakayasumi), but this period belongs to Stage II or the beginning time of Stage III, as it finishes mostly only over a few days.

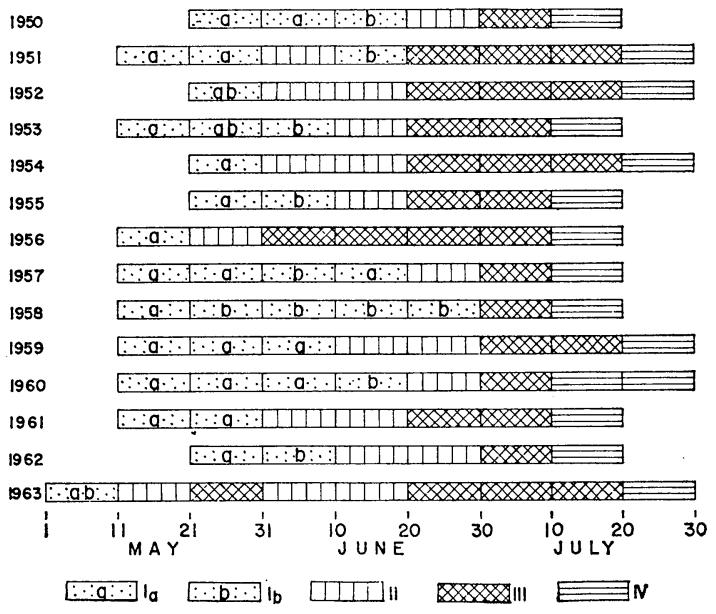

Fig. 2. Chronicle of Stages I-IV in 1950-1963.

above, Stages in the rainy season for 19501963 were determined as shown in Fig. 2.

First of all, it can be said that, as a mean state, the middle and last ten days of May are Stage $I_{a}$, the first ten days of June Stage $\mathrm{I}_{\mathrm{b}}$, the middle ten days of June Stage II, the last ten days of June Stage II or III, the first ten days of July Stage III without exception, and the middle ten days of July Stage IV.

Difference in the time of appearance for each Stage by year is not small. Stage $I_{a}$ appeared once in the first ten days and five times in the last ten days of May. As compared with this, Stage $I_{b}$ took place more irregularly: Some years lacked Stage $\mathrm{I}_{\mathrm{b}}$, some years had this Stage in the first ten days of May as a complex feature like Stage $\mathrm{I}_{\mathrm{ab}}$, and some years, for example 1958, gave it in the four ten days, from the last ten days of May to the last ten days of June.

Stage II also showed a great year by year difference. For instance, the difference between the earliest case and the latest one reached five ten days. Stages III and IV had smaller differences by year in the respective occurring times than that of Stage II. Stage IV ended in ten days in most cases, showing the smallest variation by year.

\section{Macro-scale situations of Stages I-IV}

i) Patterns of 500-mb contours over the northern hemisphere

The typical cases of each Stage were chosen for making composite maps of $500-\mathrm{mb}$ contours over the northern hemisphere, as given 
in Figs. 3-6: Stage I-May 11-20, 1961, and May 21-30, 1962. Stage II-May 31-June 9, 1961, June 20-29, 1962, and June 10-19, 1963. Stage III-June 30-July 9, 1961, June 30-July 9, 1962, and June 30-July 9, 1963. Stage IVJuly 10-19, 1961, and July 20-29, 1963.

In Stage I (Fig. 3), the north polar region is occupied by the low, $5280 \mathrm{gpm}$, in contrast to the high over SE-Asia and the Pacific.

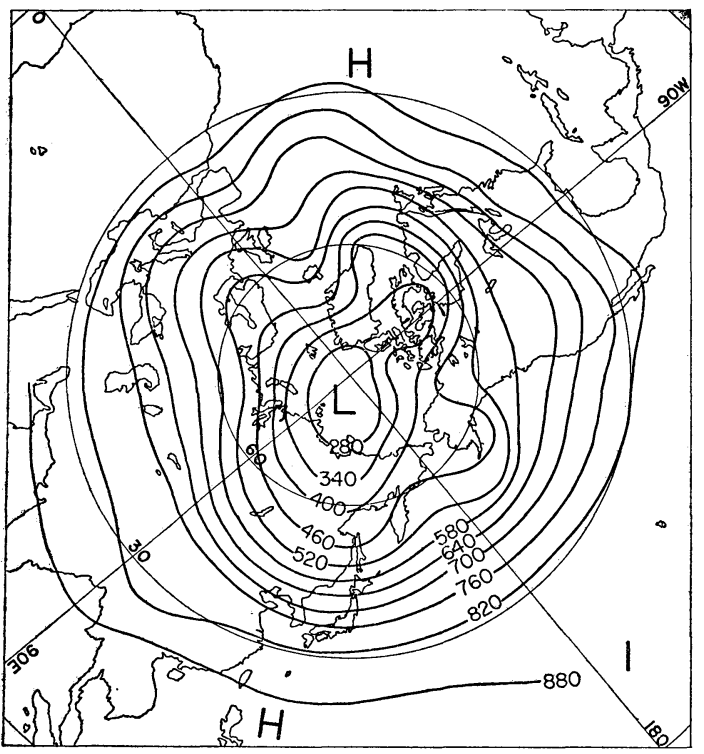

Fig. 3. $500-\mathrm{mb}$ contours in Stage I over the northern hemisphere. $(+5000 \mathrm{gpm})$

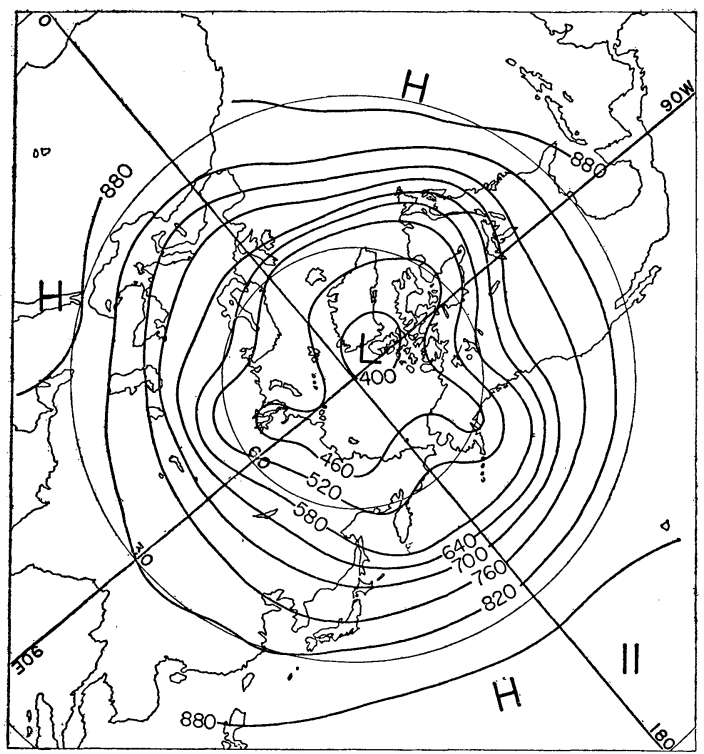

Fig. 4. 500-mb contours in Stage II over the northern hemisphere. $(+5000 \mathrm{gpm})$
This global situation is still a winter type. Because of trough in the eastern part of Siberia, the meridional gradient over East Asia is strong.

Stage II (Fig. 4) shows already a summer type, indicating a sudden increase of the low, $5400 \mathrm{gpm}$, in the polar region. The high areas more than $5880 \mathrm{gpm}$ situate over the Pacific, the Atlantic and Eastern Africa. From Hima-

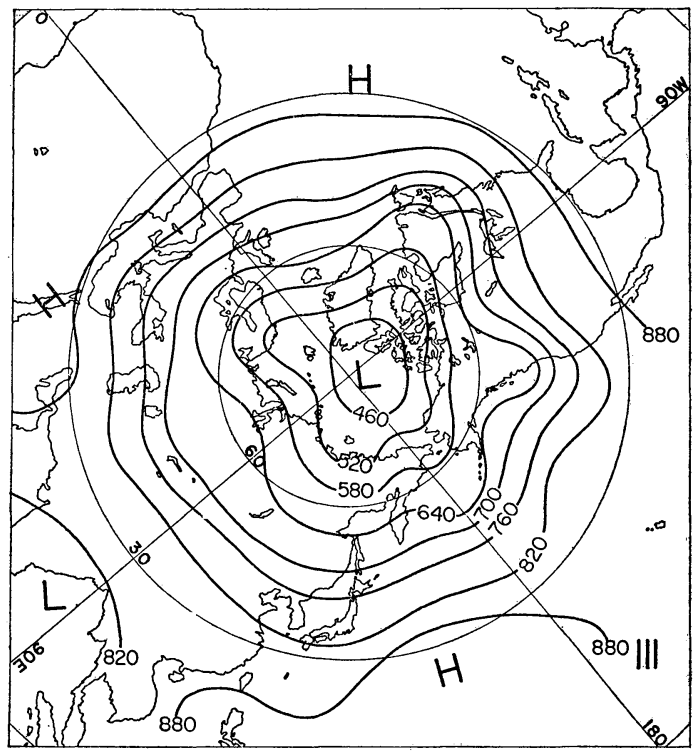

Fig. 5. 500-mb contours in Stage III over the northern hemisphere. $(+5000 \mathrm{gpm})$

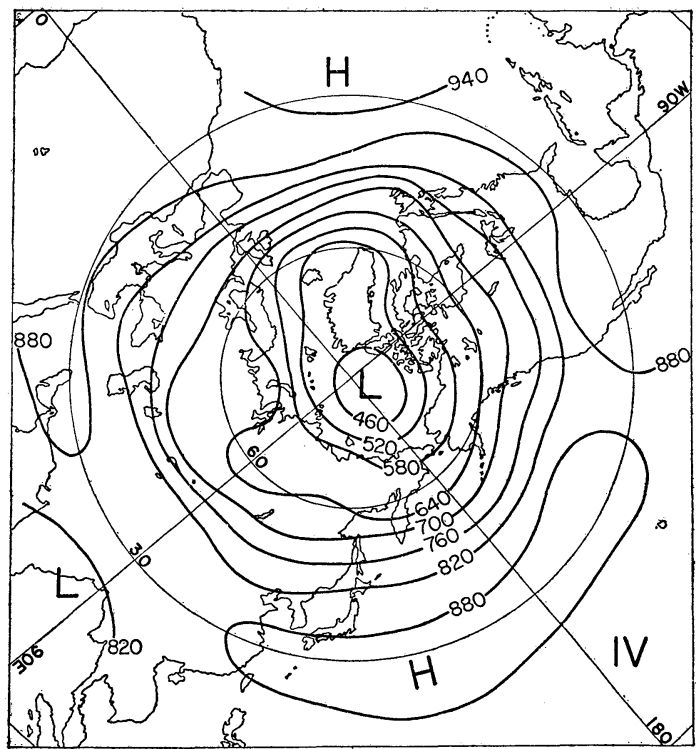

Fig. 6. $500-\mathrm{mb}$ contours in Stage IV over the northern hemisphere. $(+5000 \mathrm{gpm})$ 
laya to northern India, there appears a tendency to a low area.

In Stage III (Fig. 5), this low area strengthens its tendency. This is a characteristic situation in the advance of the season from May to July, as has been essentially shown in the monthly mean charts over India and neighbourhood (Ramakrishnan et al., 1960). In a study on the pressure patterns of the northern hemisphere during the periods of the rainy season in 1930-1934, Suda has pointed out that the high areas were formed in western Europe, in central Siberia and over the sea of Okhotsk, which bring the rainy season in Japan, and at the same time, the low areas occurred in the Pacific coast of Alaska, Atlantic coast of Canada and northern Europe (Suda, 1955). These low areas correspond perfectly with the localities of the troughs in Stage III.

In Stage IV (Fig. 6), the low area in the polar region remains as $5400 \mathrm{gpm}$ and the high area, $5880 \mathrm{gpm}$, over the Pacific becomes a definite shape. Over India and its neighbourhood there appears a typical situation, that is, the low areas in the north and the south, and the high areas in the west and the east. This situation has been presented as a mean circulation of summer in the charts for July previously published (Data 4, Staff Members Acad. Sinica, 1957). The high area in the east was more apparently illustrated on the charts of $500-\mathrm{mb}$ contours for July and August by Flohn (1957).

From the facts found on the pattern of $500-\mathrm{mb}$ contours over the northern hemisphere, it can be summarized that Stage I belongs to winter and, on the contrary, Stage II and later ones to summer.

The contours of the northern hemishere at the $100-\mathrm{mb}$ level for several ten days in May, June and July, 1957, have been briefly discussed by Imada (1963). According to the figures presented by him, it is given that the stages in the present study show characteristic features: (1) Height of the low over high latitudes around the pole changed apparently in Stage III (16600 gpm) from that of the preceding Stage (16400 gpm). (2) In Stage III, the high $(16800 \mathrm{gpm})$ over South Asia shifted to the north and, at the same time, expanded to East Asia. (3) In Stage
IV, East Asia was occupied completely by this high, but its center went back to northern India.

Recently, it was pointed out that, when the high at the 100-mb level left the Tibetan Plateau, the West Pacific subtropical high at the $500-\mathrm{mb}$ lebel advances to the continent (to west) and, on the contrary, when the former returned to the Plateau, the latter retreated from the continent. Mai-yü in the Yangtze region occurred in accordance with this oscillation (Dao and Chu, 1964). Accordingly, it may be said that Stages III and IV are the time when the high at the 100 -mb level extends eastward from the Plateau and the high at the $500-\mathrm{mb}$ level advances to the continent from the Pacific.

ii) Patterns of zonal winds at the $500-\mathrm{mb}$ level over East Asia

Distributions of the zonal component of geostrophic wind velocity $(\mathrm{m} / \mathrm{s})$ at the $500-\mathrm{mb}$ level over East Asia were given in Figs. 7(a)(f). The maps were made by the mean value of 1959-1963 for each ten days.

Fig. 7 (a) presents a state of the pre-rainy season; the axis of westerly wind maximum runs along the southern side of Himalaya (Tibetan Plateau) and this is strengthened $(20 \mathrm{~m} / \mathrm{s}$ or more) over Japan and the Pacific. In Stage I shown in Fig. 7(b), this westerly wind is weakened and, on the other hand, another axis of westerly wind maximum, running from Siberia to Japan, comes down. From this axis towards north, the wind velocity decreases gradually.

In Stage II, the axis of westerly wind maximum, subtropical one, along the southern side of Himalaya (Tibetan Plateau) diminishes and the other one with weak intensity, coming down from the north, locates over Mongolia as given in Fig. 7 (c). In Stage III, the axis along the southern side of Himalaya (Tibetan Plateau) becomes perfectly extinct and, in contrast to this, the weak but distinct one flows from Central Asia, via southern Mongolia, Yellow Sea and Japan, to the Pacific. To the south of $25-30^{\circ} \mathrm{N}$, there appears a characteristic easterly region in this Stage. Although it is not found in the mean map like the present one, because of its positional variation year by year, the weak easterly region locates in Stage III in almost every 

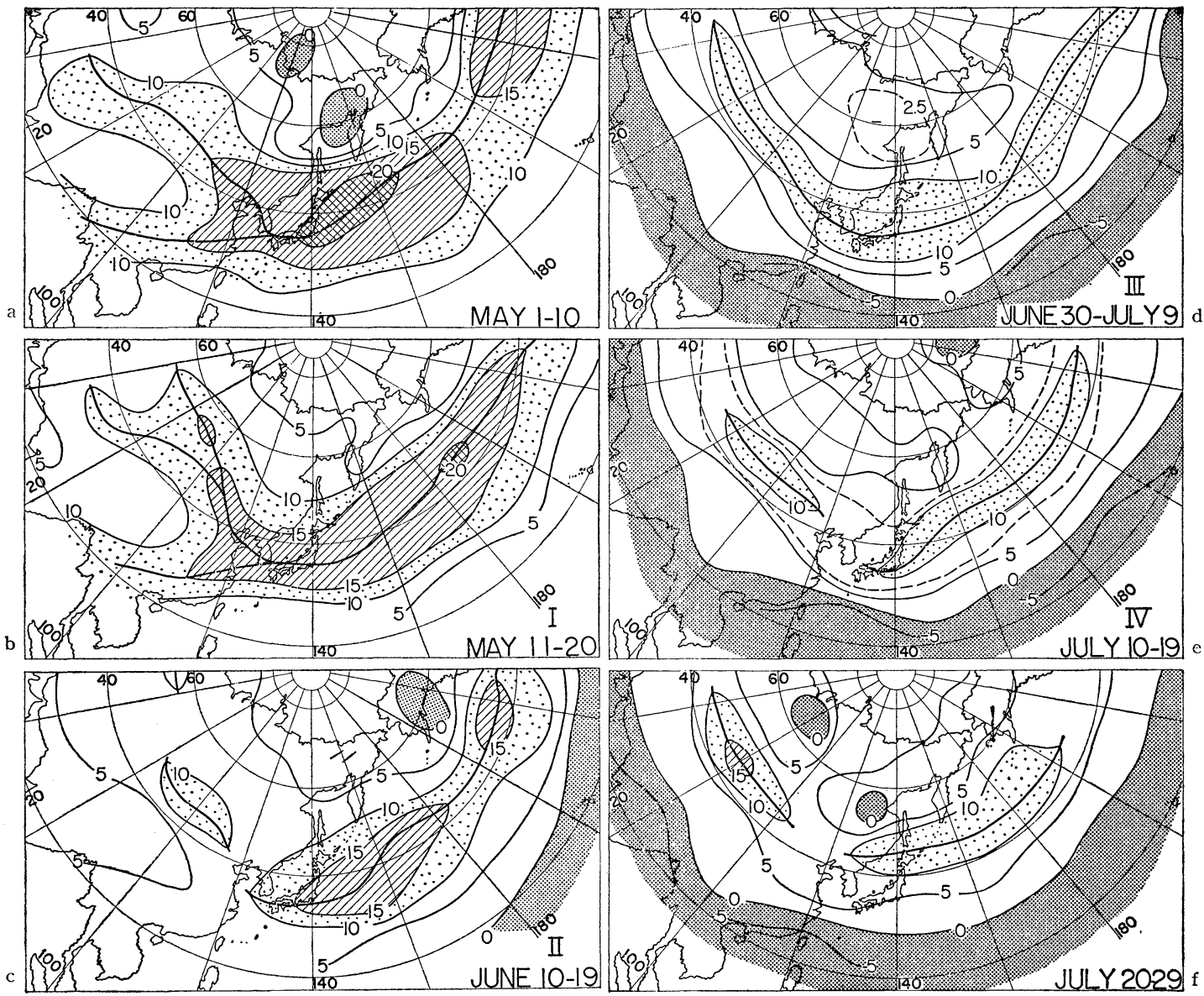

Fig. $7(\mathrm{a})$-(f). Distribution of geostrophic wind velocity $(\mathrm{m} / \mathrm{s})$ at the $500-\mathrm{mb}$ level in each Stage over East Asia. Westerly : positive.

year in the Okhotsk Sea or near there. This is caused by meandering of the westerly in high latitudes.

In Stage IV, as shown in Fig. $7(\mathrm{e})$, the axis from Mongolia to the Pacific, via Japan, becomes again weaker and goes up to $45^{\circ} \mathrm{N}$, excepting only the part of $140^{\circ} \mathrm{E}$. The disappearance of the subtropical axis along $35^{\circ} \mathrm{N}$ indicates the cease of Bai-u season in Japan, as has been pointed out by Murakami (1951, 1955) and also that of Mai-yü period in China (Staff Members Acad. Sinica, 1957). Therefore, it must be noticed, in view of the zonal wind patterns over East Asia at the $500-\mathrm{mb}$ level, that Stage IV is the situation of post rainy season. But a local, heavy rainfall tends to happen, because of the active front which appears only for a short time.

Fig. 7 (f) gives the pattern of post rainy season, in other words, dry season. This is a true summer situation: The weak jet stream along $45^{\circ} \mathrm{N}$ from Siberia to the Pacific and the easterly area up to $30^{\circ} \mathrm{N}$ are characteristic.

Summarizing the change of the zonal wind patterns at the $500-\mathrm{mb}$ level over East Asia, the following can be said: Stage I is the continuation of the winter situation in general. Stage II gives a summer-like position of the axis of westerly wind maximum around the Tibetan Plateau, but over Japan the axis still takes a winter-like position and the easterly region occupies further south. In Stage III this easterly region comes up and the stational, westerly winds over East Asia is strengthened. Stage IV is the summer pattern.

Showing the pressure patterns and the positions of axis of westerly wind maximum at the $500-\mathrm{mb}$ level over the northern hemisphere, the stage before Bai-u, early time of 
Bai- $u$, late Bai- $u$ and the stage after Bai- $u$ in 1949 were described by Murakami (1955). According to the results obtained in the preceding parts of the present paper and referring to those in his paper, it may be concluded that (1) the change of the pressure pattern over the northern hemisphere from winter type to summer one takes place between Stages I and II. (2) After that time there occurs no fundamental changes in patterns in Stages II and III. If we pay attention to the circumstances of westerly wind patterns and the easterly regions over East Asia, however, those in Stage III show the most intensified characters of the rainy season.

The conditions of pressure pattern and zonal winds at the $500-\mathrm{mb}$ level in Stage IV belong to a summer type.

iii) States of the vertical profile of zonal wind along $140^{\circ} \mathrm{E}$

In this part of study, the states of vertical profile of zonal wind including the stratosphere were mentioned for each Stage. Up to the present, there have been published many studies on the profile along some meridional cross-sections. However, they have not yet shown the detailed states of the stratosphere in the rainy season. Using the charts of profiles along $140^{\circ} \mathrm{E}$ for every day, 1958 (Data 5), the profiles for Stages I, III and IV were made as given in Figs. 8(a)-(c). Stage II did not appear in 1958.

In Stage I, May 11-20, 1958, there located the westerly jet stream with velocity of 40 $\mathrm{m} / \mathrm{s}$, at $38^{\circ} \mathrm{N}$ at the $200-\mathrm{mb}$ level. The westerly region was $25-50^{\circ} \mathrm{N}$ at sea level, all latitudes at the $200-300-\mathrm{mb}$ levels and $40-60^{\circ} \mathrm{N}$ at the $20-\mathrm{mb}$ level. That is to say, the easterly regions situated at the four corners in the charts of profile. The height difference of the tropopause between low and high latitudes was still great. These conditions of this Stage are generally a characteristic type in winter, as shown in Fig. 8(a).

In Stage III, June 30-July 9 1958, the situation changed completely to the summer type. The westerly jet stream became weak having two cores with velocity of $15-20 \mathrm{~m} / \mathrm{s}$ respectively. The tropopause at low latitudes became lower and that at high latitudes higher. Therefore, the difference of height at about $40^{\circ} \mathrm{N}$ was very small. The stratosphere above the 100 -mb level was occupied by the easterlies. Also, south of $25^{\circ} \mathrm{N}$ and high latitudes
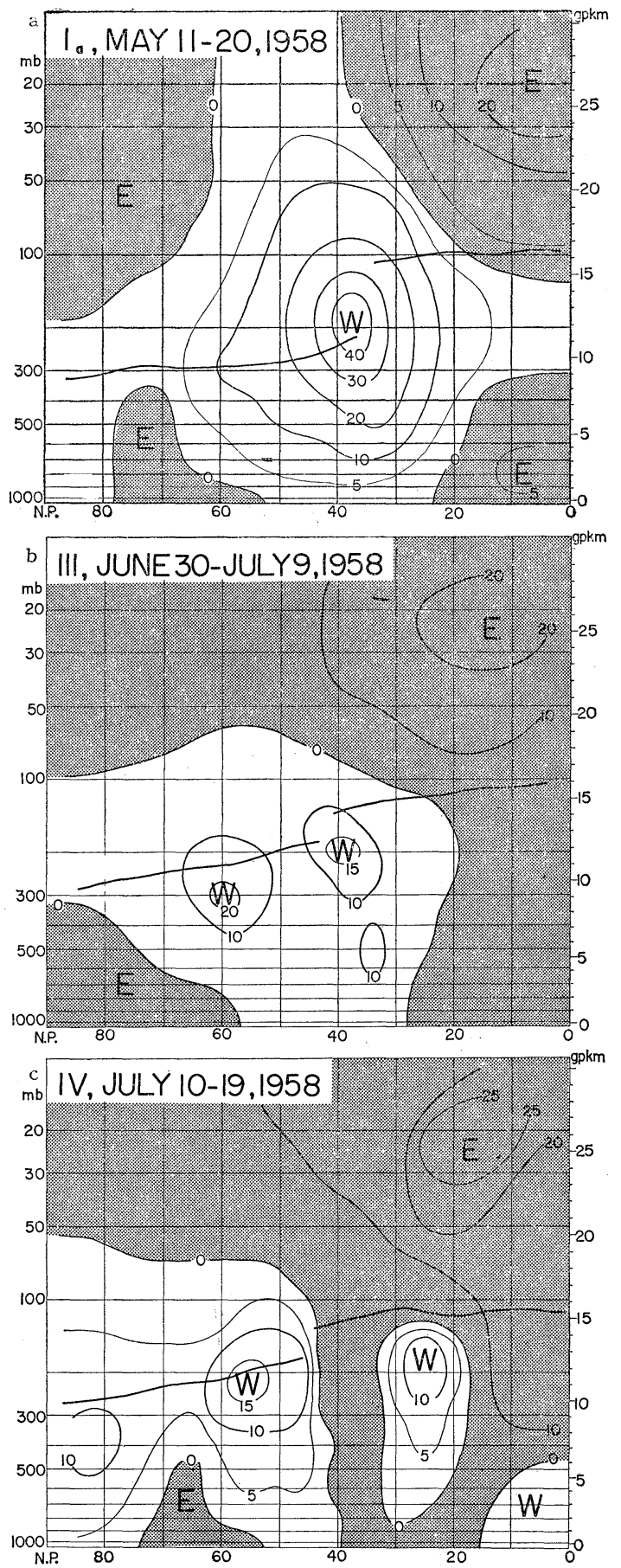

Fig. 8. Meridional profile of geostrophic wind velocity $(\mathrm{m} / \mathrm{s})$ along $140^{\circ} \mathrm{E}$ in 1958 . (a) Stage I, (b) Stage III, and (c) Stage IV. Tropopause: thick line. 
in the troposphere, there developed the easterlies.

Stage IV, July 10-19 1958, does not show any fundamental difference from Stage III. One of the striking features in summer is an appearance of the westerlies near the equator up to the $500-\mathrm{mb}$ level in the easterly region south of $40^{\circ} \mathrm{N}$ in troposphere. The tropopause declined gently from the equator to the pole. Above the $50-100-\mathrm{mb}$ levels at high latitudes, it is occupied by the easterlies. The westerly jet stream located at $25^{\circ} \mathrm{N}$ at the $200-\mathrm{mb}$ level has not yet been examined, whether it was a special case in 1958 or a normal one. It was found, however, that there existed also a westerly jet stream at $15^{\circ} \mathrm{N}$ at about the $200-\mathrm{mb}$ level, as has been shown on the month. ly mean profiles for May, June and July, $195 €$ (Neyama, 1961). This westerly jet stream at $15-25^{\circ} \mathrm{N}$ separated from those at high latitudes is not seen on the profile along $150^{\circ} \mathrm{E}$ for July illustrated by Gibbs (1953) or a cross. section for summer averaged over all longi. tudes in the northern hemisphere (Mintz, 1954). Recently, it was pointed out that there was a typical Hadley cell in the Pacific trade wind area in July 1958 (Chen, C.-s. et al., 1964). It is, therefore, in my opinion that

surface

$850 \mathrm{mb}$
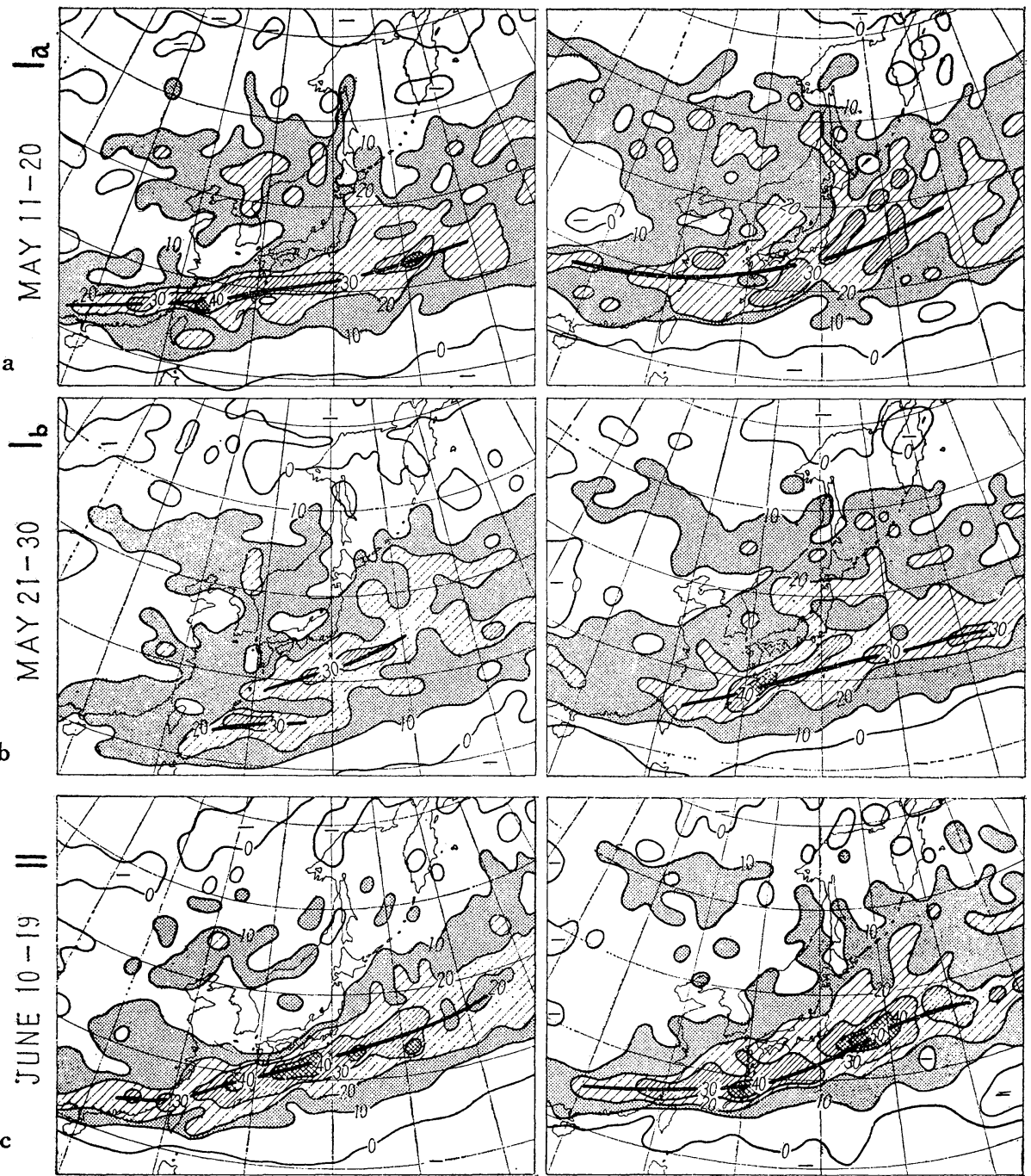

Fig. 9. Distribution of the occurrence frequency (\%) of fronts at the sea level and at the $850-\mathrm{mb}$ level in each Stage. 

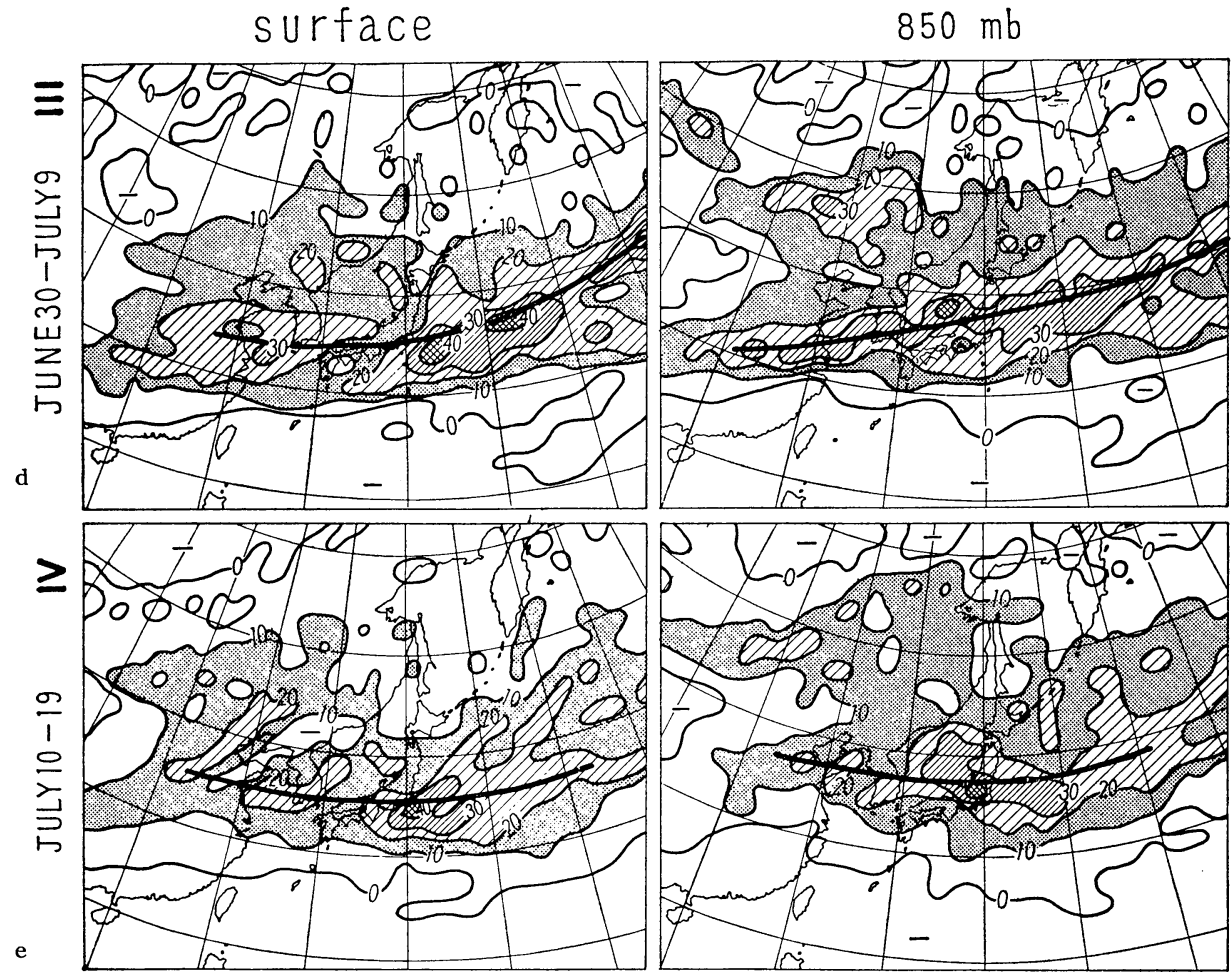

Fig. 9. (continued) Distribution of the occurrence frequency (\%) of fronts at the sea level and at the $850-\mathrm{mb}$ level in each Stage.

the detailed studies for every year, not only on the zonal or meridional winds but also on the vertical motions in the west Pacific, may come into the question in future.

The causes of change from stage to stage were not studied in the present paper, but some consideration was given. As has been pointed out, there were six or seven waves on the subtropical jet stream in the upper troposphere over the northern hemisphere during the period May 22-July 3 1958, and there occurred a sudden northward shift of the jet stream at the beginning and the end of June when the amplitude of waves increased (Chen, W.-c. et al., 1964). Therefore, it can easily be supposed that the change of situation from stage to stage in the rainy season was consistent with the increased amplitude of waves in the subtropical jet stream.

\section{iv) Frontal zones at the $850-\mathrm{mb}$ level}

The frontal zones at the sea level were dealt with in detail in the previous study (Yoshino, 1963). But, as the SW flow in East Asia plays an important role in the transport of water-vapour in the season and this SW flow concentrates in a layer $1,500-3,000 \mathrm{~m}$ (Flohn, 1950; Flohn and Oeckel, 1956; Murakami, 1959), it is thought that the frontal zones at the $850-\mathrm{mb}$ level must be analyzed in the studies on macro-scale situations in each stage.

Figs. 9(a)-(e) show the distribution of occurrence frequency of fronts at the sea level and at the $850-\mathrm{mb}$ level in Stages I-IV. These maps were taken from the previous paper (Yoshino, 1964), summarized for 19591963 (Data 2). From these figures the following conclusions are given: (1) The position of main frontal zone at the $850-\mathrm{mb}$ level is deviated $2-6^{\circ}$ latitudinally to the north from that at the sea level over China in Stage $\mathrm{I}_{\mathrm{a}}$. On the contrary, there is no positional correlation in Japan and the Pacific. (2) In Stage $\mathrm{I}_{\mathrm{b}}$, the frontal zone at the 850mb level develops at the part of Ryûkyû Rettô and deviates $3-4^{\circ}$ latitudinally to the north from that at the sea level. In the Pacific there is no definite positional deviation. (3) In Stage II, the frontal zone at the 
Table 1. Comparison of the stage division given in this paper

\begin{tabular}{|c|c|c|c|c|c|}
\hline Area studied & & East Asia & Japan & Japan & Japan \\
\hline Researcher & & $\begin{array}{c}\text { Yoshino } \\
\text { (present paper) }\end{array}$ & $\begin{array}{l}\text { Japan Meteoro- } \\
\text { logical Agency }\end{array}$ & Takahashi (1965) & Momose (1965) \\
\hline Division & Stage & & $\begin{array}{l}\text { a: beginning, } \\
\text { b: end of Bai-u. }\end{array}$ & $\begin{array}{l}\text { a: beginning, } \\
\text { b: end of Bai-u. }\end{array}$ & $\begin{array}{l}\text { a: beginning, } \\
\text { b: end of Bai-u. }\end{array}$ \\
\hline 1950 & $\begin{array}{l}\text { I } \\
\text { II } \\
\text { III } \\
\text { IV }\end{array}$ & $\begin{array}{l}\text { V. } 21-\text { VI. } 19 \\
\text { VI. } 20 \text {-VI. } 29 \\
\text { VI. } 30 \text {-VII. } 9 \\
\text { VII. } 10 \text {-VII. } 19\end{array}$ & $\begin{array}{ll}\text { a: } & \text { VI. } \\
\text { b: } & \text { VII. } \\
8\end{array}$ & $\begin{array}{l}\text { a: ? } \\
\text { b: VI. } 27\end{array}$ & $\begin{array}{ll}\text { a: } & \text { V. } 25 \\
\text { b: } & \text { VII. } 30\end{array}$ \\
\hline 1951 & $\begin{array}{l}\text { I } \\
\text { II } \\
\text { III } \\
\text { IV }\end{array}$ & $\begin{array}{l}\{\text { V. } 11-\text { V. } .30 \\
\text { VI. } 10 \text {-VI. } 19\} \\
\text { V. } 31-\text { VI. } 9 \\
\text { VI. } 20 \text {-VII. } 19 \\
\text { VII. } 20 \text {-VII. } 29\end{array}$ & $\begin{array}{ll}\text { a: } & \text { VI. } 15 \\
\text { b: } & \text { VII. } 18\end{array}$ & $\begin{array}{ll}\text { a: } & \text { VI. } 7 \\
\text { b: } & \text { VII. } 17\end{array}$ & $\begin{array}{ll}\text { a: } & \text { VI. } 5 \\
\text { b: } & \text { VII. } 17\end{array}$ \\
\hline 1952 & $\begin{array}{l}\text { I } \\
\text { II } \\
\text { III } \\
\text { IV }\end{array}$ & $\begin{array}{l}\text { V. } 21-V .30 \\
\text { V. } 31 \text {-VI. } 19 \\
\text { VI. } 20 \text {-VII. } 19 \\
\text { VII. } 20 \text {-VII. } 29\end{array}$ & $\begin{array}{ll}\text { a: } & \text { VI. } 14 \\
\text { b: } & \text { VII. } 16\end{array}$ & $\begin{array}{ll}\text { a: } & \text { V. } 28 \\
\text { b: } & \text { VII. } 22\end{array}$ & $\begin{array}{ll}\text { a: } & \text { V. } 27 \\
\text { b: } & \text { VII. } 19\end{array}$ \\
\hline 1953 & $\begin{array}{l}\text { I } \\
\text { III } \\
\text { III } \\
\text { IV }\end{array}$ & $\begin{array}{l}\text { V. } 11-\text { VI. } 9 \\
\text { VI. } 10 \text {-VI. } 19 \\
\text { VI. } 20 \text {-VII. } 9 \\
\text { VII. } 10 \text {-VII. } 19\end{array}$ & $\begin{array}{ll}\text { a: } & \text { VI. } 1 \\
\text { b: } & \text { VII. } 24\end{array}$ & $\begin{array}{ll}\text { a: } & \text { VI. } 2 \\
\text { b: } & \text { VII. } 22\end{array}$ & $\begin{array}{ll}\text { a: } & \text { V. } 28 \\
\text { b: } & \text { VII. } 23\end{array}$ \\
\hline 1954 & $\begin{array}{l}\text { I } \\
\text { III } \\
\text { III }\end{array}$ & $\begin{array}{l}\text { V. } 21-V .30 \\
\text { V. } 31-V .19 \\
\text { VI. } 20 \text {-VII. } 19 \\
\text { VII. } 20 \text {-VII. } 29\end{array}$ & $\begin{array}{ll}\text { a: } & \text { Vl. } 6 \\
\text { b: } & \text { VII. } 25\end{array}$ & $\begin{array}{ll}\text { a: } & ? \\
\text { b: } & \text { VIII. } 27\end{array}$ & $\begin{array}{ll}\text { a: } & \text { V. } 16 \\
\text { b: } & \text { VII. } 15\end{array}$ \\
\hline 1955 & $\begin{array}{l}\text { I } \\
\text { II } \\
\text { III } \\
\text { IV }\end{array}$ & $\begin{array}{l}\text { V. } 21-\text { VI. } 9 \\
\text { VI. } 10 \text {-VI. } 19 \\
\text { VI. } 20 \text {-VII. } 9 \\
\text { VII. } 10 \text {-VII. } 19\end{array}$ & $\begin{array}{ll}\text { a: } & \text { VI. } 13 \\
\text { b: } & \text { VII. } 9\end{array}$ & $\begin{array}{l}\text { a: ? } \\
\text { b: VII. } 7\end{array}$ & $\begin{array}{ll}\text { a: } & \text { V. } 11 \\
\text { b: } & \text { VII. } 8\end{array}$ \\
\hline 1956 & $\begin{array}{l}\text { I } \\
\text { III } \\
\text { IV }\end{array}$ & $\begin{array}{l}\text { V. } 11-V \cdot 20 \\
\text { V. } 21-V \cdot 30 \\
\text { V. } 31-V I I .9 \\
\text { VII. } 10 \text {-VII. } 19\end{array}$ & $\begin{array}{ll}\text { a: } & \text { V. } 22 \\
\text { b: } & \text { VII. } 21\end{array}$ & $\begin{array}{l}\text { a: ? } \\
\text { b: ? }\end{array}$ & $\begin{array}{ll}\text { a: } & \text { V. } 22 \\
\text { b: } & \text { VII. } 24\end{array}$ \\
\hline 1957 & $\begin{array}{l}\text { I } \\
\text { II } \\
\text { III } \\
\text { IV }\end{array}$ & $\begin{array}{l}\text { V. } 11 \text {-VI. } 19 \\
\text { VI. } 20 \text {-VI. } 29 \\
\text { VI. } 30 \text {-VII. } 9 \\
\text { VII. } 10 \text {-VII. } 19\end{array}$ & $\begin{array}{ll}\text { a: } & \text { VI. } 6 \\
\text { b: } & \text { VII. } 28\end{array}$ & $\begin{array}{l}\text { a: } \\
\text { b: ? }\end{array}$ & $\begin{array}{ll}\text { a: } & \text { VI. } 5 \\
\text { b: } & \text { VII. } 27\end{array}$ \\
\hline 1958 & $\begin{array}{l}\text { I } \\
\text { II } \\
\text { III } \\
\text { IV }\end{array}$ & $\begin{array}{l}\text { V. } 11 \text {-VI. } 29 \\
\text { ? } \\
\text { VI. } 30 \text {-VII. } 9 \\
\text { VII. } 10 \text {-VII. } 19\end{array}$ & $\begin{array}{ll}\text { a: } & \text { VI. } 11 \\
\text { b: } & \text { VII. } 15\end{array}$ & $\begin{array}{ll}\text { a: } & \text { VI. } 7 \\
\text { b: } & \text { ? }\end{array}$ & $\begin{array}{ll}\text { a: } & \text { VI. } 7 \\
\text { b: } & \text { VII. } 28\end{array}$ \\
\hline 1959 & $\begin{array}{l}\text { I } \\
\text { II } \\
\text { III } \\
\text { IV }\end{array}$ & $\begin{array}{l}\text { V. } 11 \text {-VI. } 9 \\
\text { VI. } 10 \text {-VI. } 29 \\
\text { VI. } 30 \text {-VII. } 19 \\
\text { VII. } 20 \text {-VII. } 29\end{array}$ & $\begin{array}{ll}\text { a: } & \text { VI. } 10 \\
\text { b: } & \text { VII. } 6\end{array}$ & $\begin{array}{ll}\text { a: } & \text { VI. } 1 \\
\text { b: } & \text { VII. } 22\end{array}$ & $\begin{array}{ll}\text { a: } & \text { VI. } 2 \\
\text { b: } & \text { VII. } 24\end{array}$ \\
\hline 1960 & $\begin{array}{l}\text { I } \\
\text { II } \\
\text { III } \\
\text { IV }\end{array}$ & $\begin{array}{l}\text { V. } 11-\text { VI. } 19 \\
\text { VI. } 20 \text {-VI. } 29 \\
\text { VI. } 30 \text {-VII. } 9 \\
\text { VII. } 10 \text {-VII. } 29\end{array}$ & $\begin{array}{ll}\text { a: } & \text { V. } 27 \\
\text { b: } & \text { VII. } 18\end{array}$ & $\begin{array}{lll}\text { a: } & \text { VI. } & 2 \\
\text { b: } & \text { VII. } & 9\end{array}$ & $\begin{array}{ll}\text { a: } & \text { V. } 26 \\
\text { b: } & \text { VII. } 8\end{array}$ \\
\hline 1961 & $\begin{array}{l}\text { I } \\
\text { II } \\
\text { IIV }\end{array}$ & $\begin{array}{l}\text { V. } 11-V \cdot 30 \\
\text { V. } 31-V I .19 \\
\text { VI. } 20 \text {-VII. } 9 \\
\text { VII. } 10 \text {-VII. } 19\end{array}$ & $\begin{array}{ll}\text { a: } & \text { VI. } 9 \\
\text { b: } & \text { VII. } 15\end{array}$ & & $\begin{array}{ll}\text { a: } & \text { VI. } \\
\text { b: } & \text { VII. } 5\end{array}$ \\
\hline 1962 & $\begin{array}{l}\text { I } \\
\text { II } \\
\text { III } \\
\text { IV }\end{array}$ & $\begin{array}{l}\text { V. } 21-\text { VI. } 9 \\
\text { VI. } 10 \text {-VI. } 29 \\
\text { VI. } 30 \text {-VII. } 9 \\
\text { VII. } 10 \text {-VII. } 19\end{array}$ & $\begin{array}{ll}\text { a: } & \text { VI. } 3 \text { or } 8 \\
\text { b: } & \text { VII. } 12\end{array}$ & & \\
\hline 1963 & $\begin{array}{l}\text { I } \\
\text { II } \\
\text { III } \\
\text { IV }\end{array}$ & $\begin{array}{l}\text { V. } 1 \text {-V.10 } \\
\{\mathrm{V} \cdot 11-\mathrm{V} \cdot 20 \\
\mathrm{V} \cdot 31-\mathrm{VI} \cdot 19 \\
\mathrm{~V} \cdot 21-\mathrm{V} \cdot 30 \\
\mathrm{VI} \cdot 20-\mathrm{VII} \cdot 19 \\
\text { VII. } 20-\mathrm{VII} \cdot 29\end{array}$ & $\begin{array}{l}\text { a: V. } 6 \\
\text { b: VII. } 24\end{array}$ & & \\
\hline
\end{tabular}


with those determined by the other researchers.

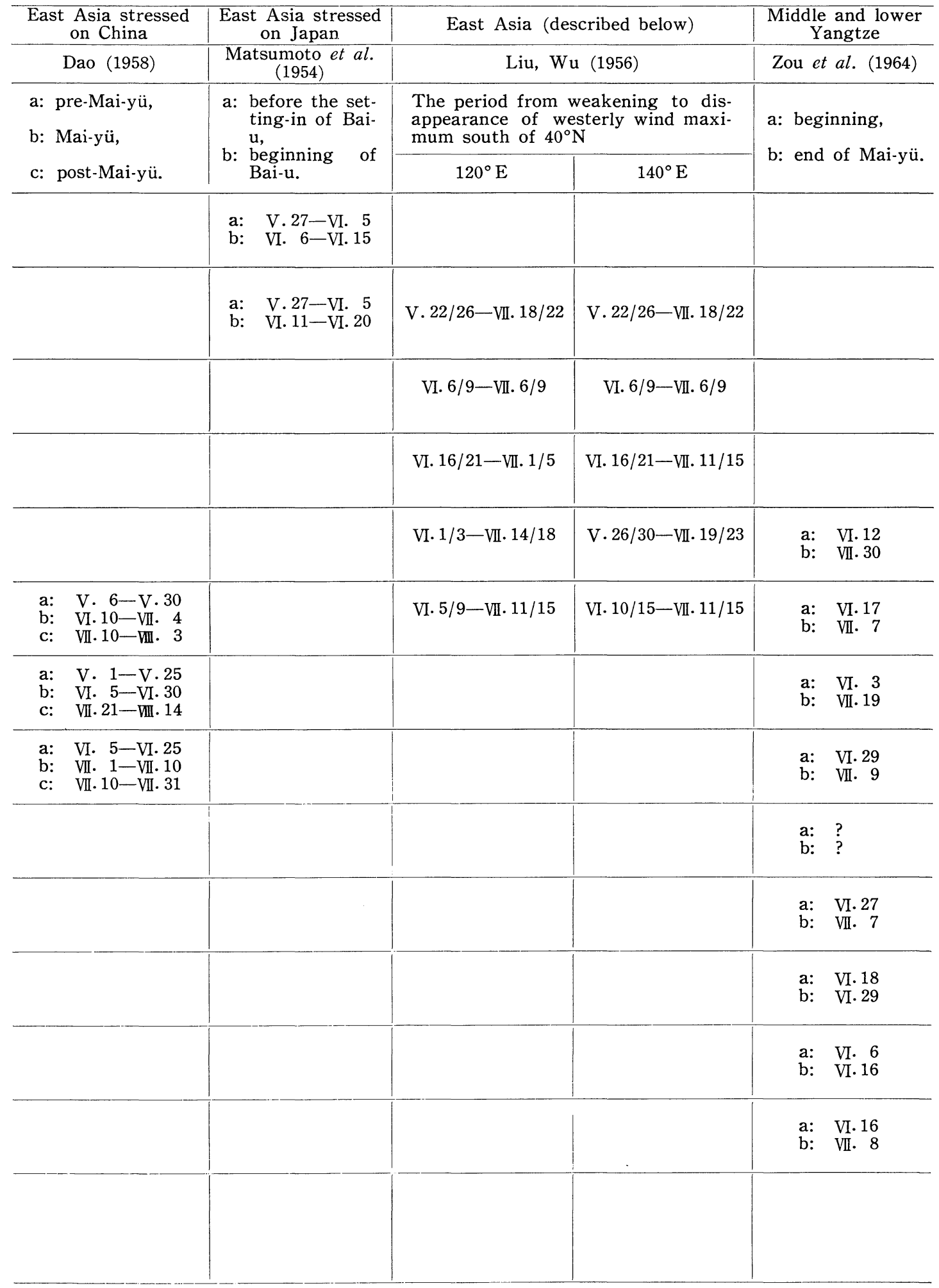


850-mb level develops well together with that at the sea level. It is worthy to note that there is no positional deviation in any part of East Asia: in China, along the southern coast of Japan and in the Pacific. (4) In Stage III, also the marked frontal zone prolongs at the 850 -mb level. However, the opposite tendency on the positional deviation to the preceding Stages begins to develop; that is, in China the frontal zone at the 850 -mb level locates almost at the same position (or somewhat south !) to that at the sea level and in the Pacific, east of Japan, that at the $850-\mathrm{mb}$ level deviates $2-3^{\circ}$ latitudinally to the north from that at the sea level. (5) In Stage IV, there is no positional correlation in China and, on the contrary, $2-4^{\circ}$ latitudinal deviation is found in the area around Japan and in the Pacific like in Stage III.

These changes of the positional deviation between the $850-\mathrm{mb}$ and the sea levels according to the progress of Stages seem to have been occurred in accordance with the change of the front structure. A more detailed study on this point must be needed.

\section{Comparison of the present division of Stages with the others'}

The beginning and last dates have been decided from various standpoints by many research-workers and also some more detailed divisions of the rainy season have been tried in several studies. In this part of study, I intend to make comparison of the present division, concerning Stages I-IV, with the others'. Table 1 was presented for comparison's sake.

Before the discussion, it must be noticed that the criteria of division, the regions considered and the meteorological elements in the studies are different between the present one and the others'. At the same time, the sort of materials, for instance, five-day-running mean value, half decade value, long year mean for each day and so on, must be taken into consideration. In this paper, as was mentioned earlier, the materials were calculated for every ten days, which were divided from January 1 . On this account, it is difficult to seek out complete coincidence of period in the comparison.

First of all, the beginning and last dates of the rainy season in Japan determined by the Japan Meteorological Agency is put into discussion. The division was made considering the synoptic situation over East Asia stressed upon Japan and her surroundings: anticyclone centered in the Sea of Okhotsk overlies the eastern sea area of North Japan, stational front runs along the Pacific coast of Japan and the stagnat, cloudy weather prevails all over Japan. According to the division by the Japan Meteorological Agency, the Bai-u season begins in Stage I or in some years Stage II and ends in the last part of Stage III or in Stage IV. It is rare that the Bai-u season ceases after Stage IV.

Takahashi and Momose presented the beginning and last dates of the Bai-u season in Japan, based upon the sunshine duration (Takahashi, 1965). Their beginning dates fall in Stage I. It is of interest that frequency of their coincidence with the beginning of Stage I is greater than that of the Japan Meteorological Agency decided on the synoptic situations mentioned above. Their last dates fall also in the last period of Stage III or in Stage IV.

Considering the patterns of geostrophic wind and the position of jet stream at the 850-200-mb levels, the division of stages has been made for Mai-yü in China (Dao, 1958) and for Bai-u in Japan (Matsumoto et al., 1954). As shown in Table 1, the pre-Mai-yü by Dao and the Bai-u by Matsumoto et al. coincide well with Stage I. The Mai-y 1 period by Dao corresponds to Stages II through III or only Stage III. The beginning of postMai-yü concurs satisfactorily with that of Stage IV. The reason for this is of course that the criteria of stage division in the present paper and Dao or Matsumoto et al. are quite similar.

Liu and $\mathrm{Wu}$ (1956) gave a table on the beginning and last dates of the rainy season over East Asia, for 1951-1955, paying attention to the period from weakening to disappearance of the low latitude westerly wind maximum. Comparing this division with the present one, the periods determined by them coincide with the last time of Stages II through III. Another division in the lower and middle Yangtze region by Zou et al. (1964), the beginning occurred in Stage II and the 
end in Stage III in most years. The fact that the end in this region appeared in general earlier than that in Japan must be noteworthy.

In this connection, it can be pointed out that the period in May and June, excluding late June, called as the time of Bai-u stream in South China and Southwest Japan by Ramage (1952), corresponds to Stage I or Stages I and II and, therefore, his division may be applicable only to South China and not whole East Asia.

As has been shown in the preceding parts of this study, the upper easterly region goes up from lower latitudes to north Stage by Stage. On this account, the appearance of upper easterlies in May and June at $22-26^{\circ} \mathrm{N}$ is a striking fore-rurning phenomenon of the beginning and the end of rainy season over East Asia, as pointed out previously (Yoshino, 1963). This fact was discussed using the wind data at the 200 or the $150-\mathrm{mb}$ level at Bahrein $\left(26^{\circ} 16^{\prime} \mathrm{N}, 50^{\circ} 37^{\prime} \mathrm{E}\right)$, Calcutta $\left(22^{\circ} 32^{\prime} \mathrm{N}, 88^{\circ} 24^{\prime} \mathrm{E}\right)$, Hong Kong $\left(22^{\circ} 18 \mathrm{~N}, 114^{\circ} 10^{\prime} \mathrm{E}\right)$, Hengchun $\left(22^{\circ} 00^{\prime} \mathrm{N}, 121^{\circ} 45^{\prime} \mathrm{E}\right)$ and other stations by $\mathrm{Dao}$ and Chen (1957), Dao (1958) and Ramanathan (1960). On the other hand, the change of tropopause height at Marcus Is. $\left(24^{\circ} 17^{\prime} \mathrm{N}\right.$, $153^{\circ} 58^{\prime} \mathrm{E}$ ) (Neyama, 1955) and also the replacement of the westerlies by the easterlies at the $200-\mathrm{mb}$ at the same place (Neyama, 1963a, b) occurred about one month before the beginning of Bai-u at Kagoshima, Southwest Japan. Comparing the dates of the first appearance of this easterlies at $18 \mathrm{~km}$ at Marcus Is. for 1953-1961 (Neyama, 1963a) with the dates of each Stage given in Table 1, it seems that they tend to occur (half of the cases occurred) about one month before the time in Stage II. It must be said, however, that a precise comparison will be meaning-less, because the dates determined by Neyama were based on data at the single point for every day and Stages presented in this paper were based on the conditions over East Asia for every ten days. I like to suggest here that a more detailed study on the advance of the easterlies in the upper troposphere and the stratosphere in May and June over South Asia and the Pacific is needed in future.

\section{Summary}

In this paper the rainy season in early summer over East Asia was divided into four stages, based upon the position of frontal zones at the sea level and the zonal components of geostrophic wind velocity at the $500-\mathrm{mb}$ level for five-day mean along $120^{\circ} \mathrm{E}$ and $140^{\circ} \mathrm{E}$. The ten days of Stages I-IV appeared in May, June and July, 1950-1963, were given in the calendar (Fig. 2).

Then, by analysing the states of macroscale situations in each stage, the followings can be concluded:

(1) On the pattern of $500-\mathrm{mb}$ contours over the northern hemisphere, Stage I belongs to winter type: Sharp difference between high and low latitudes. But Stage II and later ones show the type of summer character: The weakened low over the pole and the developed high over the Pacific.

(2) On the pattern of zonal wind at the 500mb level over East Asia, Stage I has no characterisitc change from winter circulation type. Stages II and III are transitional periods: The subtropical axis of westerly wind maximum around the Tibetan Plateau takes a summer-like position, but it takes winter situations over and around Japan in Stage II. The region of the easterlies comes up from lower latitudes, but the westerly winds over East Asia are generally strengthened in Stage III. Stage IV is socalled summer type; the axis of westerly winds goes up to the north.

(3) On the vertical profiles of zonal wind including the stratosphere along $140^{\circ} \mathrm{E}$ in 1958, Stage I showed a typical winter type: Strong westerly winds at middle latitudes. In Stage III, the situation changed completely to the summer type: The easterlies prevailed in all the stratosphere, and also in the troposphere to the south of $25^{\circ} \mathrm{N}$ and in its high latitudes. Stage IV did not show any fundamental difference from Stage III.

(4) The frontal zones at the $850-\mathrm{mb}$ level is deviated $2-6^{\circ}$ latitudinally to the north from that at the sea level over China in Stage I. In Stage II there are no positional deviations. In Stages III and IV, the deviation is $2-3^{\circ}$ over Japan and the Pacific.

The comparison of the present division of Stages with the others' came to the following conclusion: There found a fairy good 
correlation between the present division and the others' determined synoptically considering the evidences over East Asia. However, ones determined for some limited places or by certain restricted elements do not show any good parallelism in the changes of date and Stages by year.

\section{Acknowledgments}

The writer is indebted to Dr. K. Takahashi, Meteorological Research Institute, Tokyo, for helpful discussions in the course of study and Lec. Dr. Dr. Y. Masai, Ochanomizu University, for assistance in English wording of this paper.

\section{References}

Chen, C.-s., et al., 1964: A comparison of mean wind field and mean meridional circulation between south-west monsoon area in south-east Asia and Pacific trade wind area in July, 1958. Acta Meteor. Sinica, 34, 51-61.

Chen, W.-c., et al., 1964: A synoptic analysis of the evolution of general circulation in the upper troposphere of the northern hemisphere during the period of early summer, 1958. Acta Meteor. Sinica, 34, 41-50.

Dao, S.-y., and Chen, L.-s., 1957: The structure of general circulation over continent of Asia in summer. 75th Ann. Vol J. meteor. Soc. Japan, 215-229.

Dao, S.-y., 1958: The relationship between May$y \ddot{u}$ in Far East and the behaviour of circulation over Asia. Acta Meteor. Sinica, 29, 119-134.

Dao, S.-y. and Chu, F.-k., 1964: The 100-mb flow patterns in southern Asia in summer and its relation to the advance and retreat of the westPacific subtropical anticyclone over the Far East. Acta Meteor. Sinica, 34, 385-396.

Flohn, H., 1950: Studien zur allgemeinen Zirkulation der Atmosphäre. Ber. Deutsch. Wetterd. U.S. Zone, 18, 1-52.

Flohn, H. and Oeckel, H., 1956: Water vapour flux during the summer rains over Japan and Korea. Geophys. Mag., 27, 527-532.

Flohn, H., 1957: Large-scale aspects of the summer monsoon in South and East Asia. 75th Ann. Vol. J. meteor. Soc. Japan, 180-186.

Gibbs, W.J., 1953: A comparison of hemispheric circulation with particular reference to the western Pacific. Quart. J. Roy. meteor. Soc., 79, 121-136.

Imada, M., 1963: On the relation between Bai-u and the $100-\mathrm{mb}$ circulation near Japan. Tenki, 10, 196-198.
Kao, Y.-s. and Shih, S.-y., 1962: The advance and retreat of the monsoon and the beginning and end of the rainy season in East Asia. Some problems on monsoons in East Asia (in Chinese), 78-87.

Liu, K.-n. and Wu, H.-s., 1956: A preliminary study on the determination of natural synoptic summer season over Asiatic natural synoptic region and the prevailing weather process in this season. Acta Meteor. Sinica, 27, 219-242.

Matsumoto, S., et al., 1954: An aerological study on the presummer rainy season in Japan. $J$. meteor. Soc. Japan, Ser. II., 32, 85-95.

Mintz, Y., 1954: The observed zonal circulation of the atmosphere. Bull. Amer. meteor. Soc., 35, 208-214.

Murakami, T., 1951: On the study of the change of the upper westerlies in the last stage of Bai-u season (rainy season in Japan). J. meteor. Soc. Japan, Ser. II., 29, 162-175.

- 1955 : Baiu-ki no jôsô no bani tsuite (On the aerological patterns in Bai-u season). Tenki, 2, 123-128, 132.

- 1958: The sudden change of upper westerlies near the Tibetan Plateau at the beginning of summer season. J. meteor. Soc. Japan, Ser. II., 36, 239-247.

- 1959: The general circulation and watervapour balance over the Far East during the rainy season. Geophys. Mag., 29, 131-171.

Neyama, Y., 1955: On the analysis of Bai-u season with particular reference to the tropopause height at Marcus Isle. J. meteor. Res., 6, 592-598.

- 1961: A study on Ogasawara high during spring to Bai-u season (I). J. meteor. Res., 13, 21-29.

- 1963a: On the dates of the transition of wind direction from west to east in the lower stratosphere at Marcus Island in late spring and of the setting-in of "Bai-u", the rainy season in Japan. Geophys. Mag., 31, 633-651.

,$- 1963 \mathrm{~b}$ : Note on practical method of seasonal forecasting of Bai-u by aerological data at Marcus island. J. meteor. Soc. Japan, Ser. II., 41, 247-254.

Oosawa, K., 1951: A normal broad-weather cycle in the "Baiu", the rainy season in Japan. Papers in Meteor. and Geophys., 2, 45-51.

Ramage, C.S., 1951: Analysis and forecasting of summer weather over and in the neighbourhood of South China. J. Meteor., 8, 289-299.

- 1952: Variation of rainfall over South China through the wet season. Bull. Amer. meteor. Soc., 33, 308-311.

Ramakrishnan, K. P., Sreenivasaiah, B. N. and Venkiteshwaran, S.P., 1960: Upper air clima- 
tology of India and neighbourhood in the monsoon seasons. Symp. on Monsoons of the World, 3-34.

Ramanathan, K.R., 1960 : Monsoons and the general circulation of the atmosphere. Symp. on Monsoons of the World, 53-64.

Staff Members, Acad. Sinica, Peking, 1957: On the general circulation over Eastern Asia (I). Tellus, 9, 432-446.

Suda, K., 1955: On the north high situation in the Far East as a link of hemispherical pressure distribution. Rep. Univ. Electro-Comm., (7) 59-71.

Suda, K. and Asakura, T., 1955: A study on the unusual "Bai-u" season in 1954 by means of northern hemisphere upper air charts. $J$. meteor. Soc. Japan, Ser. II., 33, 233-244.

Takahashi, K., 1955: Dôkikôgaku (Dynamic climatology). Iwanami Shoten, Tokyo. $316 \mathrm{pp.}$

_-___ 1965: Bai-u kikan no kimekatani tsuite (On the determination of Bai-u period). Yohôkentôkai-shiryô, Japan Meteor. Agency, 149-163.

Tang, M.-t., 1957: On the blocking situation on the eastern Asia and its climatic effects. Acta Meteor. Sinica, 28, 282-293.

Thompson, B.W., 1951: An eassay on the general circulation of the atmosphere over Southeast Asia and the West Pacific. Quart. J. Roy. meteor. Soc., 77, 569-597.

Tu, C.-w., Hwang, S-s., 1944: The advance and retreat of the summer monsoon in China.
Meteor. Mag., 18, (Bull. Amer. meteor. Soc., 26, 9-22, or Coll. Sci. Pap., Meteor., 1954, 519534.).

Yoshino, M.M., 1963: Rainfall, frontal zones and jet streams in early summer over East Asia. Bonner meteor. Abhandlungen, 3, 1-127.

- 1964: Frontal zones and precipitation distribution in the rainy season over East Asia. Geog. Rev. Japan, 38, 14-28.

Zou, H., Qian, Z.-q., Zhu, C.-y. and Qiang, P.-g., 1964: An analysis on the $500 \mathrm{mb}$ circulation during Mai-yü period in the lower and middle Yangtze. Acta Meteor. Sinica, 34, 174-184.

\section{Data sources}

(1) Yoshino, M.M. 1961: Atlas on the occurrence frequencies of fronts in the Bai-u season, (1) and (2). (Mimeograph)

(2) Yoshino, M.M., 1964: Atlas on the occurrence frequencies of fronts in East Asia: (1) At the sea level in May, June and July. (2) At the $850-\mathrm{mb}$ level in May, June and July. (Mimeograph)

(3) Japan Meteorological Agency (Central Meteorological Observatory): Daily weather maps.

(4) U.S. Weather Bureau 1952: Normal weather charts for the northern hemisphere. Tech. Pap. No. 21.

(5) Japan Meteorological Agency 1964: Daily series, IGY aerological cross-sections II, Pt. II, along $140^{\circ} \mathrm{E}$.

\title{
東アジアにおける雨季の 4 段階について（I）
}

\author{
吉 野 正 敏 \\ 東京教育大学理学部
}

東アジアに括ける初夏の雨季を 4 段階の第 $\mathrm{I} \sim \mathrm{IV}$ 期飞区分した。区分の基礎は, 地上飞沶ける旬別の前線帯の出現 状態と, $500 \mathrm{mb}$ 面飞拈ける $120^{\circ} \mathrm{E}$ と $140^{\circ} \mathrm{E}$ 飞沿う半旬平均の地衡風の東西成分のアイソプレスを画いてその上飞 おける状態とによった。1950 1963 年の 5 月・6 月・7 月の各旬と括ける第 I 〜 IV 期のカレンダーを図に示した。

次飞, 北半球の $500 \mathrm{mb}$ の等圧面高度図, 東アジアの $500 \mathrm{mb}$ 面の地衡風の東西成分の分布図, 地衡風の東西成分 や圈界面の 1958 年の各期についての $140^{\circ} \mathrm{E}$ 飞沿う断面図, 地上と $850 \mathrm{mb}$ 面に抢ける前線带の分布図を, 第 $\mathrm{I} \sim$ IV期飞ついてまとめた。その結果, 第 I 期は冬の状態の続きで, 第II期から夏の型に転じ, 第IV期では真夏の状態に 高層ではなっていることがわかった。最後に, 今回の第 I 〜 IV 期の区分によるカレンダーと, 他の研究者による雨季 の区分とを比較検討した。 